\title{
DIPLOMACIA UNIVERSITARIA ACADEMICA ARGENTINA NO BRASIL
}

\author{
Dr. D. José Leon Suarez.
}

Acabo de receber a importantissima obra do Sr. Dr. D. José Leon Suarez, que veio á luz da publicidade sob o titulo de Diplomacia Universitaria Academica Argentina no Brasil. E' uma copiosa noticia dos actos da missão universitaria chefiada pelo douto professor argentino, que encantou ésta capital com suas admiraveis conferencias, em que, a par da vasta erudição, mostrava o dom singular, rarissimo mesmo, de tornar interessantes a um auditorio numeroso questões altamente scientificas. A idéa-mãe do trabalho do mestre, que elle diz inspirada pelo nosso patricio Dr. Sá Vianna, não é, como parece á primeira vista, a união sul-americana, mas firmar o valor que devem ter os intellectuaes ao menos nos momentos graves da vida dos povos. Já a Europa isto comprehendeu, e, durante a tragica conflagração cuja hora terminal soou ha pouco, vimos, entre os nomes dos ministros, os de pessoas de quem o publico mal suspeitava a existencia, e que eram conhecidissimas nos meios scientificos: Nitti, Orlando, Clémenceau, etc.

Muitas dessas conferencias do Dr. Suarez cujo transumpto se acha na obra de que estou a occupar-me já eram conhecidas do público brasileiro, quer por audição directa, quer pela leitura na imprensa de nossa patria.

Dos varios ramos do Direito, é o Internacional o que menos se vulgarizou, circumstancia que, de algum modo, 
como bem diz Ihering, concorre para o tornar mais technico, mais conforme, em suas construcções, aos principios scientificos e logicos. Tambem delle só se fala, fóra dos "penetralibus pontificum", nos momentos de subversão social, nos cataclysmos que fazem periclitar as instituições humanas. Duas vezes vi pela imprensa debatidas questões dessa sciencia: durante a revolta da armada, e agora, por occasião da última guerra. Conhecida é de todos a anecdota do antigo advogado que, tendo ouvido falar em uti possidetis, ao discutir-se assumpto internacional, julgou que a locução tinha precisamente o valor que the era ligado no Direito Privado. O Marechal Floriano, cujas qualidades ninguem em bôa fé contestará hoje, nem mesmo acreditava na existencia de uma lei internacional, suppondo, soldado ignorante que era, ser o Direito Internacional o canhão: si fôra vivo ao tempo da conflagração, teria visto que ha forças muito mais poderosas que o canhão, cujo poder o assombrára, e acima do qual nada conhecia em sua esphera limitada de estudos.

Tornarei, porém, á obra do illustre professor argentino. Em um volume de mais de 600 paginas, traz as várias conferencias que pronunciou em nossa patria, em cujo numero estão as que formam um estudo da alta importancia que teve o general Mitre, tão nosso conhecido. Muitos appendices enriquecem a obra, cujas paginas são attrahentes, e, provavelmente, a muitos, do mesmo modo que a mim, evocam horas de doce prazer passadas em uma companhia agradabilissima, quaes são as que correm, quando nos achamos ao lado de collegas intelli. gentissimos, com quem praticamos sobre assumptos de nossa predilecção.

Muitos dos que ouviram as conferencias do illustre mestre argentino não apprehenderam em toda a extensão, com toda a precisão, o modo de pensar do nosso hospede sobre as matérias de interesse politico actual, em que 
versava o seu .trabalho de fraternização sul-americana. O livro, apreciado em synthese, dá conta das idéas e dos sentimentos do mestre. E' o Dr. Suarez franca e sinceramente partidario da união sul-americana, por muitas razões, e até mesmo pela importantissima da similhança das raças. Seu patriotismo, porém, não raro, dẹixa ver. quanto é vivo, coisa muito louvavel, seu amor pelo paiz onde nasceu, pela raça de que descende. E' justamente porém, para mitigar o ardor patriotico, para evitar que se formem preconceitos de raça, que devemos procurar conhecer nossos vizinhos, que nos cumpre desenvolver nossos sentimentos de sympathia nas relações que formamos com elles, e que é conveniente fazer convergir para essa fraternização todos os nossos esforços. "Sem nos conhecermos como poderemos nos amar", dizia, ha pouco, um illustre argentino, a um brasileiro. Essa sympathia, que se desenvolve entre povos irmãos, é o mais seguro penhor de que comprehenderão os sul-americanos seus verdadeiros interesses, e de que buscarão, em vez de se hostilizar por um mal entendido patrioțismo, unir suas forças em bểneficio commum. Si não ha mal que não tenha seu lado bom, foi a conflagração européa util, por nos ter lançado aos braços dos argentinos e de outros povos sul-americanos, quando quasi inteiramente nos achavamos separados do convivio com a velha Europa. Um facto illustrará o que acabo de dizer. Não fôra a última guerra, e não estariam tão estreitas as nossas relações com o Uruguay.

Pelo que disse eu, no começo desta breve notícia sobre o monumental trabalho do mestre argentino, força me é referir, como sendo das mais interessantes, dentre as notaveis conferencias do professor, a relativa á carreira diplomatica, onde elle não condemna os estudos scientificos, mas faz um elogio da technica da profissão diplomatica, no que estou de perfeito accôrdo com seu modo de pensar. 
$\mathrm{O}$ antigo imperio brasileiro, que, em assumptos diplomaticos, foi exemplar, não se esquecia de quão importantes eram nossas relações com as republicas vizinhas, e, por isto, sempre incumbiu das missões mais espinhosas para com ellas os nossos mais illustres estadistas, buscando harmonizar a necessidade do homem technico em assumptos diplomaticos com a necessidade do profundamente versado em Direito Internacional, que raramente é o profissional na vida diplomatica. Com ser notabilissimo o estudo do professor, creio que elle unicamente põe o difficil problema de aproveitar o homem de sciencia na direcção da sorte dos povos, problema que se apresenta quer na vida interna, quer na externa dos Estados.

Não é novo problema, e já nos seculos passados queixaram-se muitos de que os philosophos eram demais philosophadores em matéria juridica, e que os legistas tinham muita falta de cultura philosophica, indispensavel para boa comprehensão da lei, e para sua feliz applicação. Raro é que algum cultor do Direito possa equilibrar seus estudos de tal modo que mereça o nome de jurista ou jurisconsulto, ligando o conhecimento da theoria com o da prática. O cavillador e o prático desprezam, as mais das vezes, o estudo da theoria, cujo valor desconhecem, e o jurisconsulto não sabe que muita coisa ha, organizada geometricamente nos gabinetes, que não póde resistir ás irregularidades da vida real. O politico profissional não tem lazeres para se illustrar no estudo dos principios que a sciencia alcançou, e poude formular, e aos quaes estão subordinadas as sociedades humanas.

Mas o sociologo, o mestre em Direito Publico, o versado em assumptos constitucionaes, o conhecedor dos segredos graças aos quaes o verdadeiro politico scientifico e o estadista realmente digno desse sonoro nome, são capazes de guiar as tendencias de um povo não têm meios de fazer conhecidos do público seus altos dotes, 
de modo a alcançarem os favores populares nos comicios eleitoraes, e, quando por uma concurrencia de circumstancias, alcançam os altos postos, não são os seus actos comprehendidos da média social que critíca e aprecia, na tribuna e na imprensa, embora sem os estudos necessarios, os modos por que são guiadas as sociedades, os grandes Estados.

Uma das partes mais importantes da excellente obra do Dr. Suarez, é, para nós brasileiros, a referente á influencia de nossos intellectuaes na Argentina, e particularmente ao papel importantissimo representado pelo Conselheiro Ruy Barbosa, por sua celebre conferencia, de cuja impressão na republica vizinha nos dá minuciosa e bellissima conta o douto professor. E' digna realmente de leitura a narrativa do modo por que electrizou nosso patricio o auditorio, de fórma a obrigar os mais emeritos diplomatas, habituados, desde longos annos, a uma compastura que tem alguma coisa da impassibilidade oriental, a, esquecendo-se de um papel que, ha tanto tempo, representam, romper em freneticos applausos aos conceitos do nosso grande homem. $\mathrm{O}$ facto prestava-se ás paginas que foram escriptas pelo professor, pois só encontra, sreio eu, outro a elle comparavel na absolvição de Ligario, que Cicero arrancou a Julio Cesar. O professor Leon Suarez emprestou-lhe todo o brilho de seu talento, como si, entrando na ordem de idéas do Conselheiro Ruy Barbosa, medisse, mestre que é em Direito Internacional, mais do que qualquer ouira pessoa, a importancia da nova era que se abria para a sciencia com a vulgarização do modo de pensar de nosso pontifice maximo em matérias juridico-sociaes.

Não cabe, porém, nos limites de uma fugidia notícia, ou breve referencia á obra do que foi, por tão rapidos dias, nosso hospede, relatar miudamente as riquezas que ella possúe. Não fôra a necessidade de encerrar a menção 
que faço da obra, tivesse espaço e tempo para mais longamente me occupar com o livro que tenho diante dos olhos, e daria aos que me honram lendo éstas linhas, traçadas ás pressas, uma transcripção dos trechos que me impressionaram profundamente, com o que teriam meus leitores certamente a impressão de quem está diante de um escrinio donde se irradiam os fulgores irisados das pedras preciosas.

Praza aos céos que muitos dos meus patricios leiam a valiosissima obra e meditem longamente sobre tudo o que disse o Dr. D. José Suarez, porque o estudo de quanto agitou em suas conferencias o illustre argentino de vistas larguissimas será parte para felicidade de nossa querida patria, que tão ditosa póde ser nesta parte do continente sul-americano, onde uma Providencia propicia parece havel-a collocado por uma graça especial.

Braz de Sousa Arruda,

Docente da Faculdade. 